\title{
SCOLIOSIS AND PARAPLEGIA
}

\author{
By H. Fromm, M.D. \\ Neurochirurgische Universitätsklinik, Frankfurt am Main, Germany
}

CORD lesions of various degrees due to vertebral deformities of non-traumatic and non-infectious origin are well known. Their treatment is a problem concerning likewise the neurologist, the orthopaedic surgeon and the neurosurgeon. As a contribution to this problem two cases of scoliosis developing paraplegia from different causes are presented.

Case I. A 45-year-old male was seen by orthopaedic surgeons for several years because of a considerable scoliosis of the dorso-lumbar spine. Over the years he had complained only of moderate backache, but was able to work as a carpenter. In July 1965 he became paraplegic within one week. On admission a rather complete paraplegia was found with a sensory level at TII. There was no motor function of the lower limbs. Bladder and bowel function was impaired.

$\mathrm{X}$-ray examination confirmed the idiopathic scoliosis of the dorsolumbar spine with its apex at T9/Tro. Lumbar puncture revealed a block to the passage of cerebro-spinal fluid.

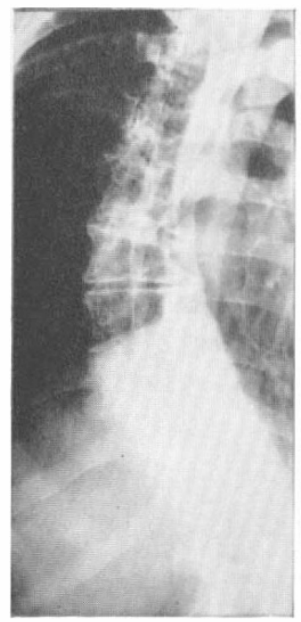

FIG. I

X-ray film, scoliosis of the dorso lumbar spine.
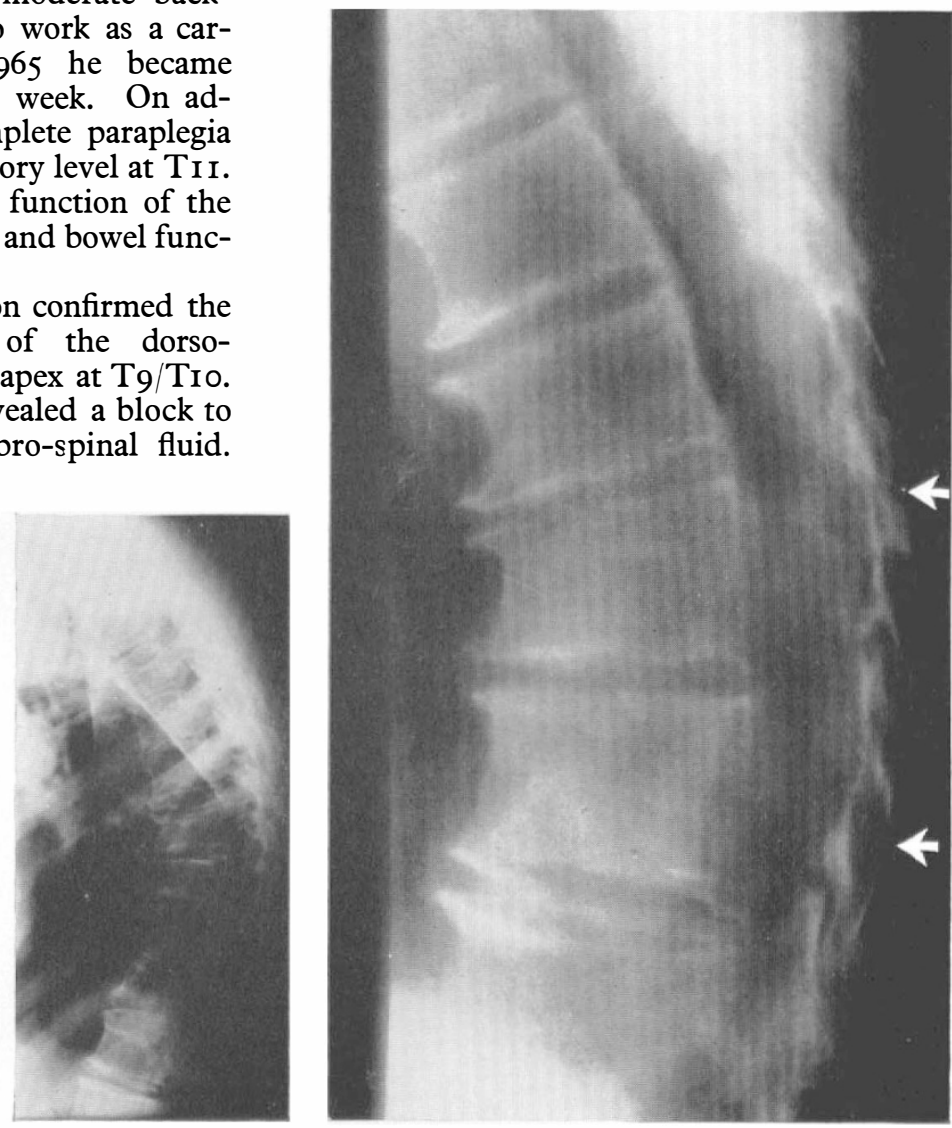

FIG. 2

Air-myelography, demonstrating a block at D9. 


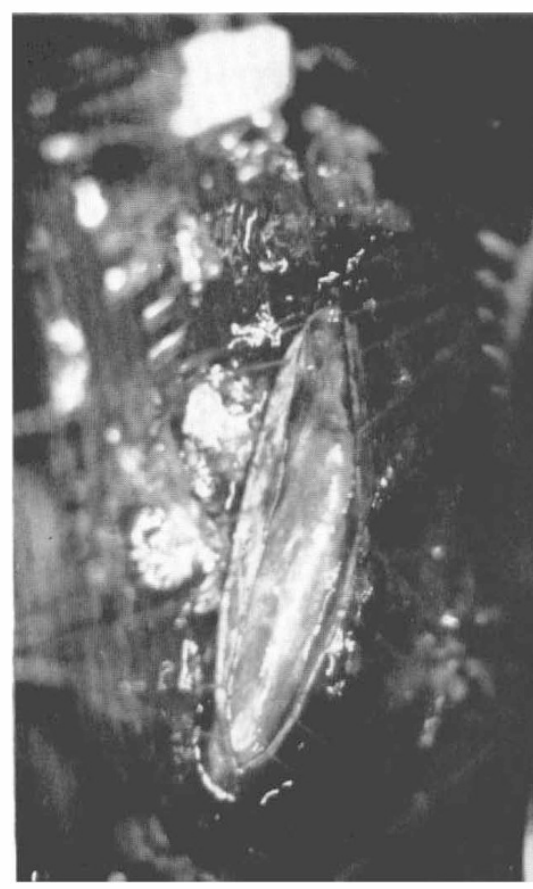

FIG. 3

FIG. 3

Situation during surgery: the cord is thickened by the intramedullary tumour.

FIG. 4

Tumour examination by microscope demonstrates an ependymoblastoma.

Fig. 5

Present state of the patient.

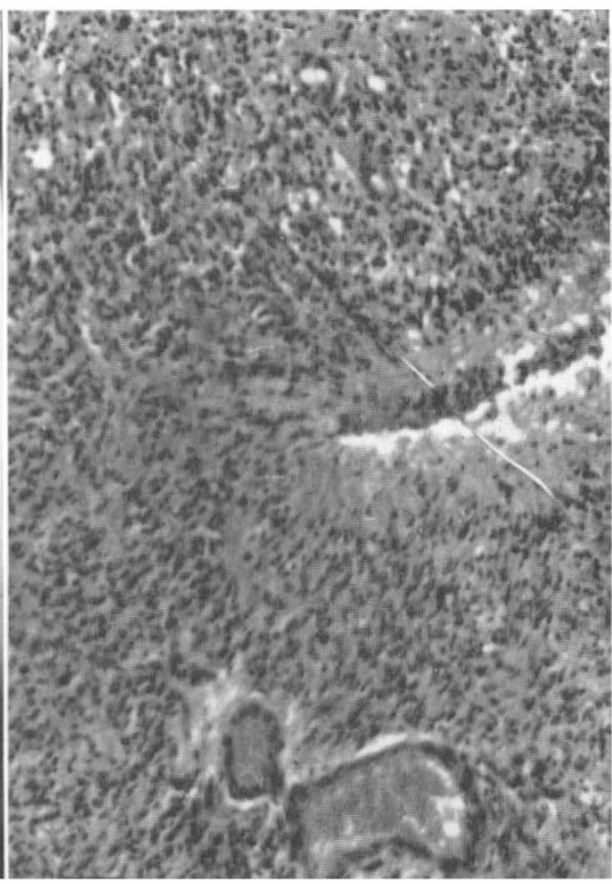

FIG. 4

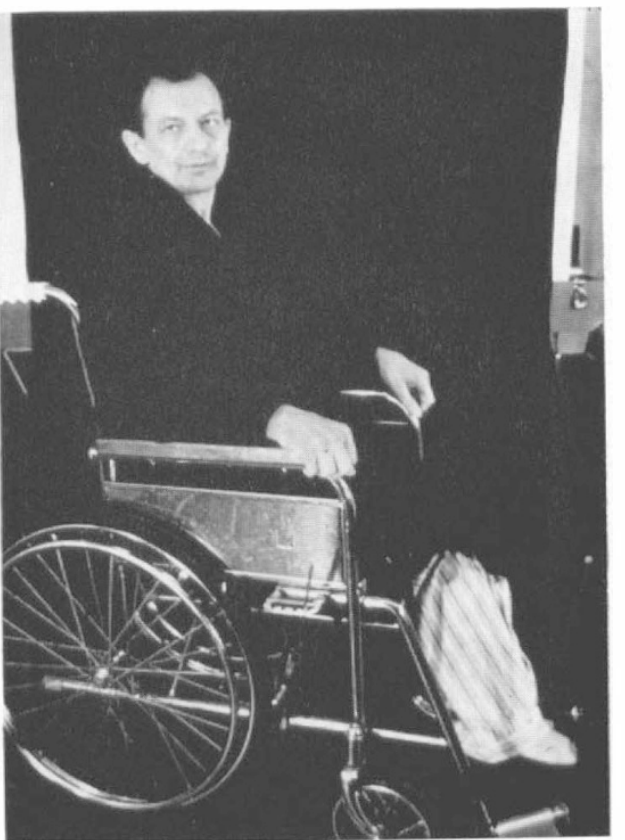

FIG. 5 
Myelography by air contrast confirmed the block at the level T9. At operation a rather localised intramedullary tumour, an ependymoblastoma, was demonstrated and removed subtotally. Later the patient underwent a gammatron-radiation of $3000 r$ and is now in a fair condition. There was no improvement of the neurological defect.

Case 2. A I7-year-old male suffering from a congenital kyphoscoliosis of the upper dorsal spine developed a progressive paraplegia within eight months. A sister of the patient also suffers from a scoliosis. There was no improvement with conservative orthopaedic treatment over several months.

On admission to neurosurgery there was found an incomplete paraplegia at the level T6. Motor function of the lower limbs was lost completely. There was found an anaesthesia up to $\mathrm{T} 8$ and a hypoaesthesia up to T6. At the perineum there was a restricted hypoaesthetic area corresponding the $S_{3}$ to $S_{5}$ segments. Bladder function was still intact.

X-ray examination confirmed an excessive congenital kyphoscoliosis of the upper dorsal spine. The Queckenstedt test revealed a block to the passage of cerebro-spinal fluid. We performed a laminectomy at the apex of the scoliosis. The laminae T2 to $\mathrm{T}_{5}$ were removed. The convexity of the opened spinal canal consisted of a compact

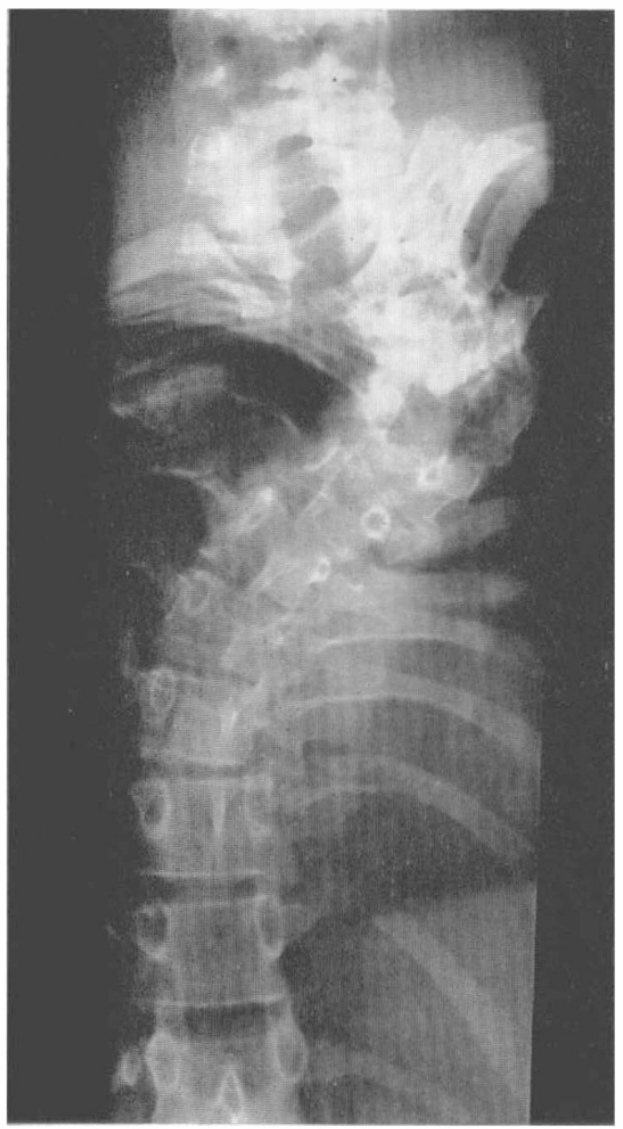

FIG. 6

$\mathrm{X}$-ray film: Excessive congenital kyphoscoliosis of the upper dorsal spine. bony mass over which the dura was stretched. After widening the spinal canal by removing nearly $\mathrm{I} \mathrm{cm}$. of this bony mass from the convexity it could be felt clearly that the narrowed cord was then without any tension. Therefore we saw no reason to open the dura. No vessels or roots were damaged or cut. There were no postoperative complications. The motor function of the lower limbs and the sensory

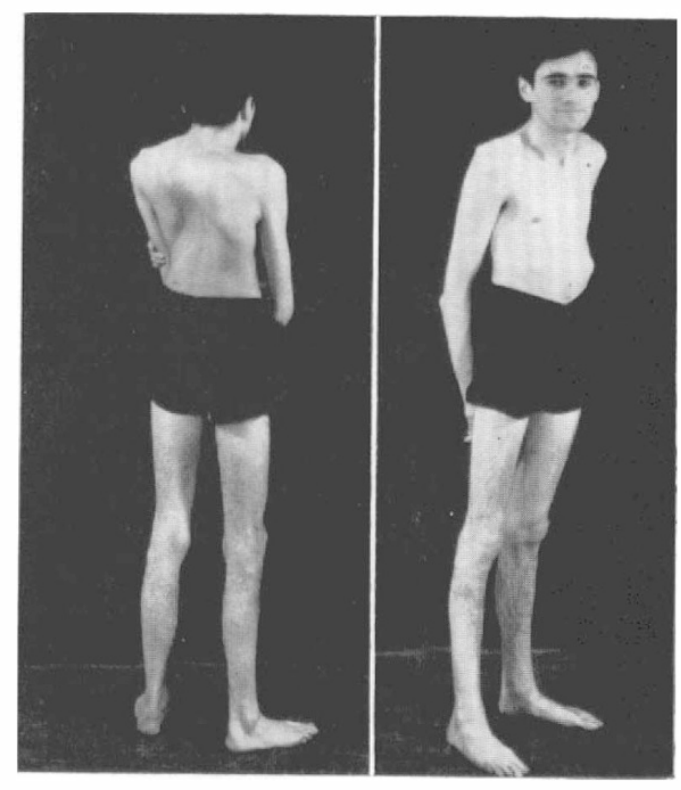

FIG. 7

Present state of the patient. 
deficit recovered completely under intensive physiotherapy within nine months. At present there is no neurological deficit except a positive Babinski sign on both sides. The patient is working full-time as a clerk.

\section{DISCUSSION}

Reviewing the literature, we found that the coincidence of congenital or idiopathic scoliosis with paraplegia is, as generally agreed, rather rare. The frequency of scoliosis together with a secondary paraplegia is assumed to be less than one-half per cent. (Steindler, 1949). Though up to date not more than about 250 cases have been published, there are reasons to believe that cases of scoliosis and paraplegia really occur in a much higher frequency (Lindemann \& Mau, 1958), especially as delayed cord lesions due to vertebral deformities are well known (Jaroschy, I928; Idelberger, I952; Kuhlendahl \& Felten, I956; Afra et al., 1966).

Adolescent patients within the age-group of to to 20 years suffering from kyphoscoliosis seem to be prone to develop paraplegia (Kleinberg \& Kaplan, I952). A disproportion between the growing spine and the cord, causing traction, torsion and compression is considered to be responsible for this phenomenon (Valentin \& Putschar, 1932; McKenzie \& Dewar, 1949; Roaf, 1964; Okonek, 1937), We are learning from experience with slowly growing intraspinal tumours that a slowly increasing cord compression may reach a considerable degree before neurological signs become evident. Thus we have to consider that not only mechanical factors but also haemodynamic dysfunctions are responsible for the development of the paraplegia. There are observations on patients suffering from severe kyphoscoliosis who developed a paraplegia during a state of cardiovascular insufficiency. After successful treatment of the cardiac decompensation the paraplegia also improved (Bodechtel \& Mittelbach, 1964).

In the literature we found only four cases of spinal tumours in combination with kyphoscoliosis: one endothelioma (Harris \& Bankart, I9I7), one lipoma, one neurinoma (Lechler, I95I), one meningeoma (Gerlach \& Spuler, 1962). Our case of an intramedullary tumour, an ependymoblastoma at the apex of the scoliosis, seems to be remarkable for the abrupt onset of the neurological signs.

In cases of patients with congenital vertebral deformities developing neurological defects early in life, other malformations related to the diastematomyeliagroup have also to be considered (Shorey, 1955; Lausberg, 1966).

\section{SUMMARY}

Every patient suffering from kyphoscoliosis producing increasing abnormal neurological symptoms needs permanent neurological supervision. If conservative orthopaedic treatment does not result soon in a significant improvement, a Queckenstedt test and, if necessary, myelography has to be performed. If there is a complete or incomplete block to the passage of cerebro-spinal fluid, surgical treatment should be performed as soon as possible.

Young and adolescent patients have an especially good chance of recovery after decompression of the cord. Normally a laminectomy is performed. If necessary bony ridges, abnormal ligaments and adhesions have to be removed. Vessels have to be preserved carefully. We consider that in many cases it is necessary to open the dura in order to get better decompression. To leave the dura open, however, would lead to the development of postoperative adhesions 
of the cord. Therefore we prefer to close the widely opened dura again by a transplant of fascia lata. Spinal tumours connected with scoliosis have to be managed according to general neurosurgical rules.

\section{RÉSUMÉ}

Tout cas d'association d'une cypho-scoliose et d'une atteinte neurologique en aggravation doit être suivi d'une façon permanente. Si le traitement conservateur orthopédique ne donne aucun changement notable, une épreuve de Queckenstedt, et si nécessaire, une myélographie doit être effectuée. En présence d'un bloc partiel, ou complet, un traitement chirurgical doit être mis en oeuvre aussitôt que possible.

Les jeunes et les adolescents ont une bonne chance de récupération après décompression. Une laminectomie est pratiquée. Si nécessaire une ablation des prominences osseuses, ligaments anormaux et adhésions est effectuée. Nous pensons qu'il est, dans beaucoup de cas, nécessaire d'ouvrir la dure-mère pour obtenir une meilleure décompression. Cependant, la dure-mère laissée ouverte peut entraîner par la suite, des adhésions de la moelle. Nous préférons donc fermer la dure-mère largement ouverte, par une transplantation du fascia-lata. Les tumeurs en rapport avec une scoliose doivent être traitées selon les règles générales de neuro-chirurgie.

\section{ZUSAMMENFASSUNG}

Jeder Patient, der an Kyphoskoliosis mit zunehmenden pathologischen neurologischen Symptomen leided, muss dauernd neurologisch überwacht werden. Wenn konservative orthopaedische Behandlung nicht bald eine wesentliche Besserung herbeiführt, sollte der Queckenstedt Test und, wenn nötig, Myelographie vorgenommen werden. Wenn ein kompletter oder inkompletter Block gefunden wird, sollte sobald als möglich operiert werden.

Insbesondere bei jungen und heranwachsenden Patienten besteht gute Aussicht auf neurologische Erholung nach operativer Dekompression des Rückenmarks. Gewöhnlich wird eine Laminektomie vorgenommen. Wenn nötig, werden knöcherne Ränder, abnormale Bänder und Verwachsungen entfernt. Blutgef ässe sollten sorgfältig geschont werden. Wir glauben, dass es in vielen Fällen besser ist, die Dura zu öffnen, um vollständige Dekompression zu erzielen. Die Dura aber offen zu lassen, würde zu postoperativen Verwachsungen des Rückenmarks führen. Wir ziehen es deshalb vor, die weit eröffnete Dura mit einem Fascia-Lata Transplant zu schliessen. Tumoren des Rückenmarks bei Skoliose sollten nach den allgemeinen neurochirurgischen Regeln behandelt werden.

\section{REFERENCES}

Afra, D., DÉAK G. \& Zoltán L. (I966). Neurochirurgia, 9, 66.

Bodechtel, G. \& Mittelbach, F. (1964). Dt. Z. NervHeilk. I 86, 4I.

Gerlach, J. \& Spuler, H. (I962). Medsche Klin. 57, 296.

HARRIS \& BANKART (I9I7). Lancet, cit. from Z. orthop. Chir. 32.

IDELBERGER (I 952). Verh. dt. orthop. Ges. 312.

JAROSCHY, W. (I928). Beitr. klin. Chir. I42, 597.

Kleinberg, S. \& Kaplan, A. (I952). F. Bone ft. Surg. 34A, i63.

Kleinberg, S. (I95I). $\mathcal{F}$. Bone ft Surg. 33A, 225.

Kuhlendahl, H. \& Felten, H. (I956). Arch. klin. Chir. 283, 96.

LAUSBERG, G. (1966). Arch. Kinderheilk (in press).

LECHLER, H. (I95I). Nervenarzt, 22, 328.

LindemanN, K. \& MaU, H. (I958). Handbuch Orthopädie II. Stuttgart.

McKenzie, K. G. \& Dewar, F. P. (I949). F. Bone ft Surg. 31B, i62.

OKoneK, G. (I937). Zentbl. Neurochir. I, 39.

RoAf, R. (I964). Paraplegia, 2, II2.

SHOREY, W. D. (1955). भु. Neurosurg. I 2, 300.

SteIndler, A. (I949). F. Bone ft. Surg. 3 IB, I73.

Valentin, B. \& PUtschar, W. (I932). Z. orthop. Chir. 57, 245. 